\title{
ASXL2 wt Allele
}

National Cancer Institute

\section{Source}

National Cancer Institute. ASXL2 wt Allele. NCI Thesaurus. Code C116297.

Human ASXL2 wild-type allele is located in the vicinity of 2 p24.1 and is approximately 145 $\mathrm{kb}$ in length. This allele, which encodes putative Polycomb group protein ASXL2, is involved in both transcriptional regulation and chromatin modification. 